\title{
Sodium Tetraphenylborate Catalyst Identification: Phase D Statistical Design Studies
}

by

M. J. Barnes

Westinghouse Savannah River Company

Savannah River Site

Aiken, South Carolina 29808

A. A. Peterson

DOE Contract No. DE-AC09-96SR18500

This paper was prepared in connection with work done under the above contract number with the U.S.

Department of Energy. By acceptance of this paper, the publisher and/or recipient acknowledges the U.S. Government's right to retain a nonexclusive, royalty-free license in and to any copyright covering this paper, along with the right to reproduce and to authorize others to reproduce all or part of the copyrighted paper.

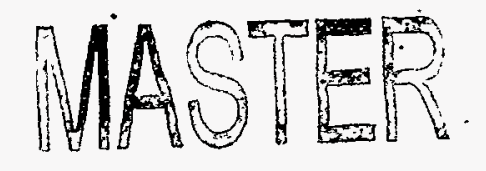




\section{DISCLAIMER}

Portions of this document may be illegible electronic image products. Images are produced from the best available original document. 


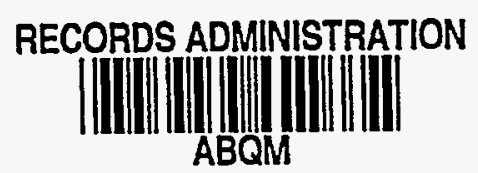

SODIUM TETRAPHENYLBORATE CATALYST IDENTIFICATION: PHASE D STATISTICAL DESIGN STUDIES (U)

M. J. Barnes

Publication Date: September 5, 1997

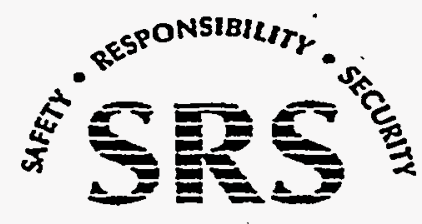


S. D. Fink

WSRC-TR-97-0275

Page 2 of 16

- Sodium Tetraphenylborate Catalyst Identification: Phase D Statistical Design Studies (U)

Author

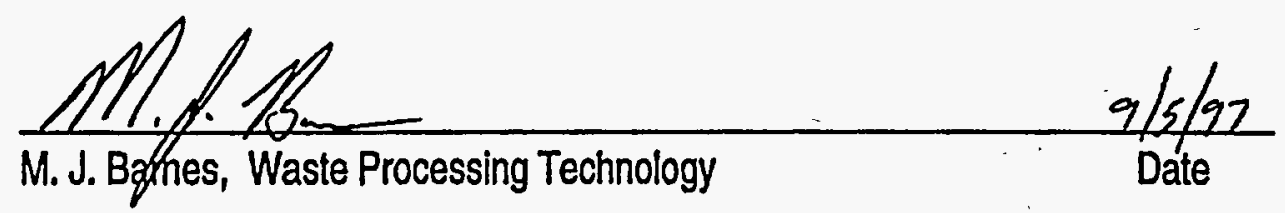

Design Check

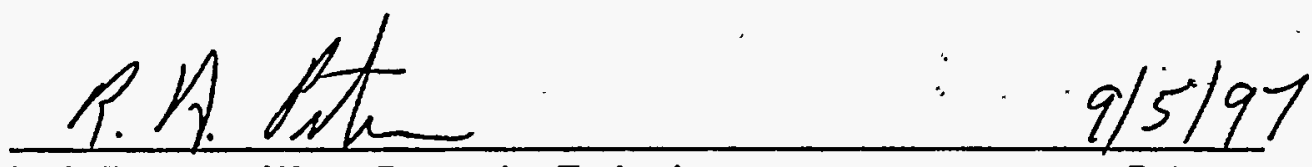

R. A. Peterson, Waste Processing Technology

Date (per Manual E7, Procedure 2.40)

Approvals

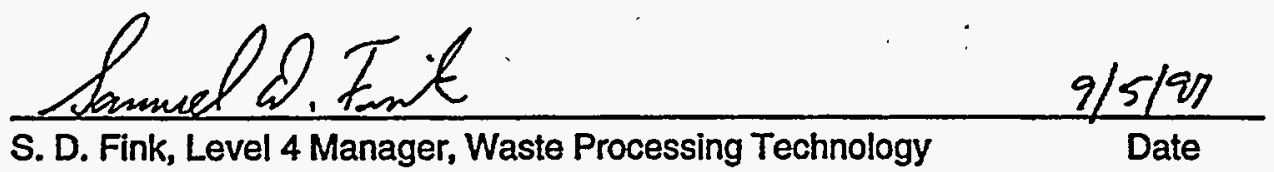

S. D. Fink, Level 4 Manager, Waste Processing Technology

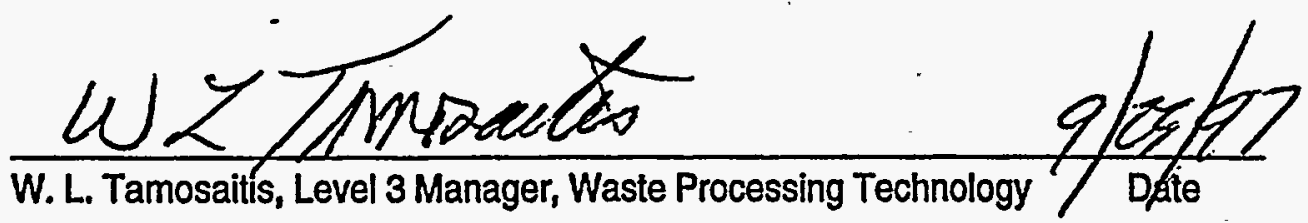

$\frac{1 \text { Carter, In-Tank Precipitation Flow Sheet Team Leader }}{\sqrt{\text { T. Con }}}$

$\frac{9 / 15 / 97}{\text { Date }}$

Nh. v. Mut

$9-16-97$

M. J. Montini, Deputy Manager, ITP/ESP Engineering

Date 


\subsection{Summary}

The decomposition of excess sodium tetraphenylborate during startup of the In-Tank Precipitation facility in 1995 is under investigation. A primary task within this investigation involves the identification of the key catalyst system responsible for the decomposition. The final stage of this task, Phase $D$, finished. Observations and conclusions drawn from Phase $D$ testing follow.

- Uranium does not catalyze decomposition under the test conditions.

- Uranium does not accelerate the previously identified palladium, diphenyimercury, benzene, and phenylborate intermediates catalytic system.

- Pre-irradiation (i.e., a 200 Mrad dose) does not accelerate catalytic decomposition.

- Continuous irradiation at a low dose rate does not accelerate catalytic decomposition.

- Testing indicates that both continuous and pre-irradiation inhibit the previously identified palladium, diphenylmercury, benzene, and phenylborate intermediates catalytic system.

This work supports resolution of DNFSB Recommendation 96-1 and the task seeking to identify the catalyst responsible for NaTPB decomposition in the In-Tank Precipitation facility.

\subsection{Introduction}

The decomposition of excess sodium tetraphenylborate (NaTPB) during the startup of the In-Tank Precipitation (ITP) process in 1995 is under investigation. [Ref. 1] A primary task within this investigation tries to identify the catalyst system responsible for the decomposition. [Ref. 2] Preliminary catalyst identification testing assessed the relative influence of reaction conditions (for example, reaction vessel, agitation, salt solution composition, and insoluble tetraphenylborate). [Ref. 3,4$]$ Statistically designed tests, to identify the key NaTPB decomposition catalysts, followed the preliminary testing. These tests evaluated 36 potential catalysts or factors. Three staged sets of tests (i.e., Phase A, B, and C) determined the key NaTPB catalyst system contained a mixture of palladium, diphenylmercury, benzene, and phenylborate intermediates (i.e., triphenylborane (3PB), diphenylborinic acid (2PB), and phenylboronic acid (1PB)). [Ref. 5, 6] Phase A tests demonstrated that a large number of the species found in ITP waste proved catalytically insignificant (relative to the aforementioned interaction). Table 1 contains a list of all active and inactive species. The concentrations listed represent values measured in samples from Tank $48 \mathrm{H}$ during the 1995 reaction. The inclusion of all chemical species (except oxygen) provides a "fullyloaded" simulant of the ITP waste and, thus, should mimic the observed NaTPB reaction. We term this simulant the Enhanced Comprehensive Catalyst, or ECC. Previous studies evaluated the reaction rates for this system. [Ref. 3 - 4]

The last stage of statistically designed catalyst identification tests (i.e., Phase $D$ ) examines the influence of one additional species, uranium, and one environmental factor, radiation, not included in Phases $A, B$, or C. - Previous tests omitted the two variables to allow for experimental flexibility (and since they were not expected to provide a significant influence). Phase $D$ testing sought to demonstrate that neither uranium nor irradiation significantly increased the rate of NaTPB decomposition. This document describes the results of Phase $D$ tests and provides the fifth report for the task [Ref. 2] designed to identify soluble NaTPB decomposition catalysts. This task, performed as part of the Defense Nuclear Facility Safety Board (DNFSB) Recommendation 96-1 Implementation Plan [Ref. 7], completes the request by High Level Waste Engineering (HLWE) and the ITP Flow Sheet Team as defined in Task Technical Request HLWTTR-97008. [Ref. 8] 


\subsection{Experimental}

\subsection{Statistical Design}

Phase $D$ tests address three specific potential influences (i.e., uranium, pre-irradiation, and continuous irradiation). Available equipment limited the continuous irradiation tests to a temperature of $45^{\circ} \mathrm{C}$.

Therefore Phase $D$ tests occurred in two sets (i.e., continuous irradiation tests at $45^{\circ} \mathrm{C}$, uranium and preirradiation tests at the prior catalyst identification testing temperature of $55^{\circ} \mathrm{C}$ ). Table 2 shows the Phase $\mathrm{D}$ statistical designs for each set of tests. Note the design includes replicates for all tests. The design looked for primary effects between the ECC system and the specific variable (i.e., either uranium, preirradiation, or continuous irradiation). Cross term effects between the three variables were unexpected and therefore not included as part of the test design. Tests requiring the ECC system added all of the inactive and active components listed in Table 1. The design did not include centerpoint tests. The table uses two values $(1,-1)$ to signify inclusion or exclusion from the test, respectively.

\subsection{Reaction Conditions}

Tests used non-radioactive simulants, with the exception of depleted uranium. Solutions added reagent grade chemicals by weighing on calibrated balances. The accuracy of glassware used to measure volumes was verified by gravimetric methods using water as a standard. [Ref. 9] Température measurements used thermometers calibrated by the SRTC Standards Laboratory. Temperature monitoring occurred at least once per day. The temperature targeted $\pm 3^{\circ} \mathrm{C}$ of the stated set point. All additional measuring and test equipment used in this task received calibration or verification for accuracy prior to use.

As noted above, Table 1 lists the concentration of ECC components. Table 2 provides the statistical design (i.e., which tests include uranium or irradiation). Typically, $55^{\circ} \mathrm{C}$ tests were monitored over two weeks and $45^{\circ} \mathrm{C}$ tests over four weeks. Based upon conclusions drawn from earlier tests (Ref. 3 and 4), all tests used sealed glass serum bottles with a nitrogen atmosphere. Each test used $2.7 \mathrm{M} \mathrm{Na}^{+}, 48 \mathrm{~g} / \mathrm{L}$ KTPB slurry containing only soluble NaTPB (i.e., no NaTPB solids). Each bottle was charged with the simulant siurry (see Table 3 ) followed by a prescribed amount of the required components (e.g., ECC or uranium). The soluble metal species came from stock solutions prepared from common salts. For the insoluble solids, the tests used simulated Purex sludge without noble metals, copper, silver, or mercury. All tests added hydrated forms of simulated sludge and MST. The soluble organic species (i.e., 3PB, 2PB, 1PB, phenol, isopropanol, and methanol) came from an alkaline stock solution. Monosodium titanate (MST), benzene, diphenylmercury, and biphenyl were added as pure compounds. Uranium, when required, was added at a target concentration of $340 \mathrm{mg} / \mathrm{L}$ in the form of depleted uranyl nitrate. The concentration is four times larger than the maximum expected (assuming $1000 \mathrm{mg} / \mathrm{L}$ sludge per batch) in any batch. [Ref. 10] Tests requiring pre-irradiation received a $200 \mathrm{Mrad}$ dose followed by addition of NaTPB, benzene, diphenylmercury, and phenylborate intermediates prior to incubation at $55^{\circ} \mathrm{C}$. This addition proved necessary since the large pre-irradiation dose likely destroyed the majority of these components. A cobalt-60 source provided the continuous irradiation dose rate of $3.1 \times E 4 \mathrm{rad} / \mathrm{h}$. A cobalt-60 source with a dose rate of $1.69 \times \mathrm{E} 6 \mathrm{rad} / \mathrm{h}$ provided the $200 \mathrm{Mrad}$ pre-irradiation dose.

In all tests, an initial filtrate sample was obtained immediately after sealing each vessel. This was analyzed by High Performance Liquid Chromatography (HPLC) to obtain starting concentrations of NaTPB, 3PB, and 2 PB. No analyses for benzene, 1PB, phenol, or soluble boron occurred. Furthermore, only NaTPB, triphenylborane, and diphenylborinic acid species were monitored in subsequent samples. Filtrate was obtained for analysis by using syringe filter discs with a $0.45 \mu$ nominal pore size to remove solids from the slurry sample. Periodic analysis of the reaction mixtures occurred during the remainder of the testing. Slurry sampling occurred after aggressive, manual shaking for approximately 15 seconds. The HPLC analysis of the filtrate from these samples allowed determination of the rate and extent of reaction. The tetraphenylborate ion (TPB') reaction rate represents the TPB' loss per unit time. 


\subsection{Results and Discussion}

Tables 4 through 17 contain concentration data for NaTPB, 3PB, and 2PB for Tests 73 through 86, respectively. Sections 4.1 through 4.4 discuss the significance of the data.

\subsection{Reaction Rates and Rate Constants}

Reaction rates for Tests 73 through 86 were calculated based only on measured soluble NaTPB concentrations from samples taken throughout the reaction period (Equation 1). The calculations used Microsoft ${ }^{\circ}$ Excel 5.0 for data regression analysis. Kinetic calculations yielded pseudo first-order rate constants for each reaction. Changes in the concentrations of soluble decomposition products (i.e., 3PB and $2 \mathrm{~PB}$ ) during the testing verify that differences $( \pm 10 \%)$ in NaTPB concentration reflect either decomposition or error in analysis. Since decomposition of NaTPB results in the production of 3PB and eventually 2PB, these measurements provide a confirmation of NaTPB decomposition (i.e., 3PB and 2PB measurements help determine if an observed change or observed variability in NaTPB reflects decomposition or analytical error). Table 18 lists pseudo first-order rate constants for Tests 73 through 86. Sections 4.2 through 4.4 provide analysis and discussion of the data.

$$
\text { Rate }=-d\left[\mathrm{NaTPB} \mathrm{dt}=\mathrm{k}[\mathrm{TPB}]\left[\text { catalyst }^{\mathrm{n}}=\mathrm{k}^{\prime}\left[\mathrm{TPB}^{-}\right], \text {where } \mathrm{k}^{\prime}=k \text { catalyst }^{\mathrm{n}}\right.\right.
$$

\subsection{Effect of Pre-irradiation}

The following summary table provides rate constants for the six tests examining the influence of preirradiation. Replicate tests show good agreemept ( $\pm 7.4 \%$ ). Rate constants marked as NRD (i.e., no reaction detected) indicate statistically insignificant changes in NaTPB concentration and limited 3PB and 2PB concentrations. Figure 1 provides graphical evidence of NaTPB decomposition with respect to time. Despite the lower starting NaTPB concentration for the four pre-irradiated tests, the data conclusively demonstrate that the most reactive tests contained the ECC system that was not pre-irradiated. Preirradiated simulants without the ECC system proved unreactive. Pre-irradiation of simulants containing the ECC system resulted in reduced rate constants. The most probable cause of this observation involves palladium or diphenylmercury deactivation by reduction. Analysis of Tests 75 and 76 after an extended length of time (i.e., 6 weeks) demonstrated that the deactivation persists under reaction conditions. The slow rate of decomposition observed in Tests 75 and 76 exceed that of previously observed copper catalysis $\left(1.7 \mathrm{E}-\dot{4} \mathrm{~h}^{-1}\right.$ ). [Ref. 11] (Note that the copper rate constant was derived from tests without radiation. This rate might also decrease in the presence of radiation.)

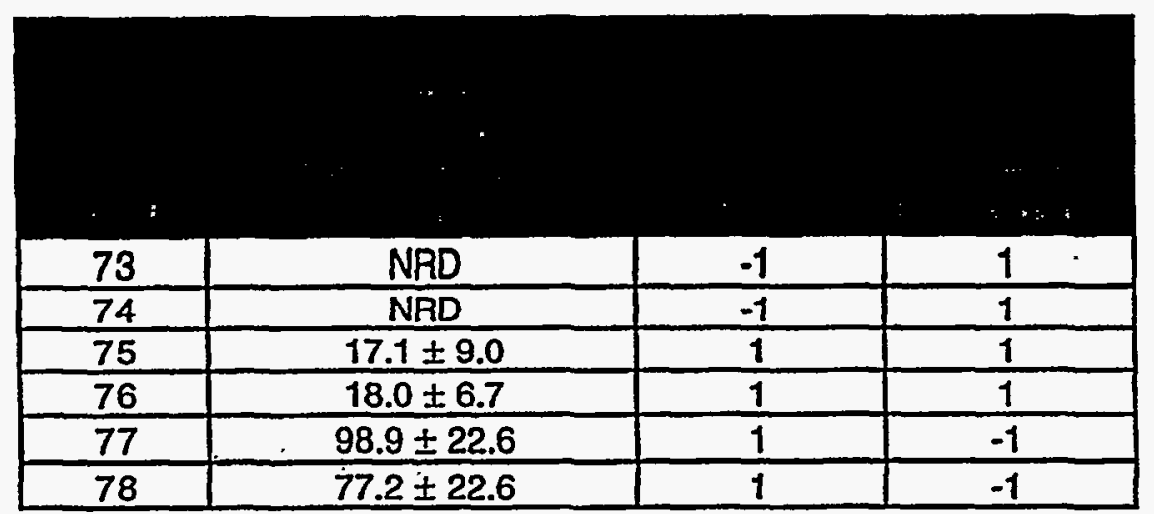

'Obtained from equation, Rate $=-d[\mathrm{NaTPB}] / \mathrm{dt}=\mathrm{k}$ TPB $]\left[\right.$ Catalyst ${ }^{n}=\mathrm{k}^{\prime}[\mathrm{TPB}]$, where $\mathrm{k}^{\prime}=k\left[\right.$ Catalyst ${ }^{\mathrm{n}}$ "NRD represents "no reaction detected" and indicates [TPB] data variance not statistically significant at a $95 \%$ confidence level. 3PB and 2PB data verifies the lack of reaction.

$c_{-1}$ indicates the ECC system absent from the test. 1 indicates the ECC system present with concentrations listed in Table 1.

$d-1$ indicates the test was not pre-irradiated. 1 indicates the test was pre-irradiated. 
Figure 1. Demonstration of the effect of 200 Mrad pre-irradiation on tests with and without the ECC system.

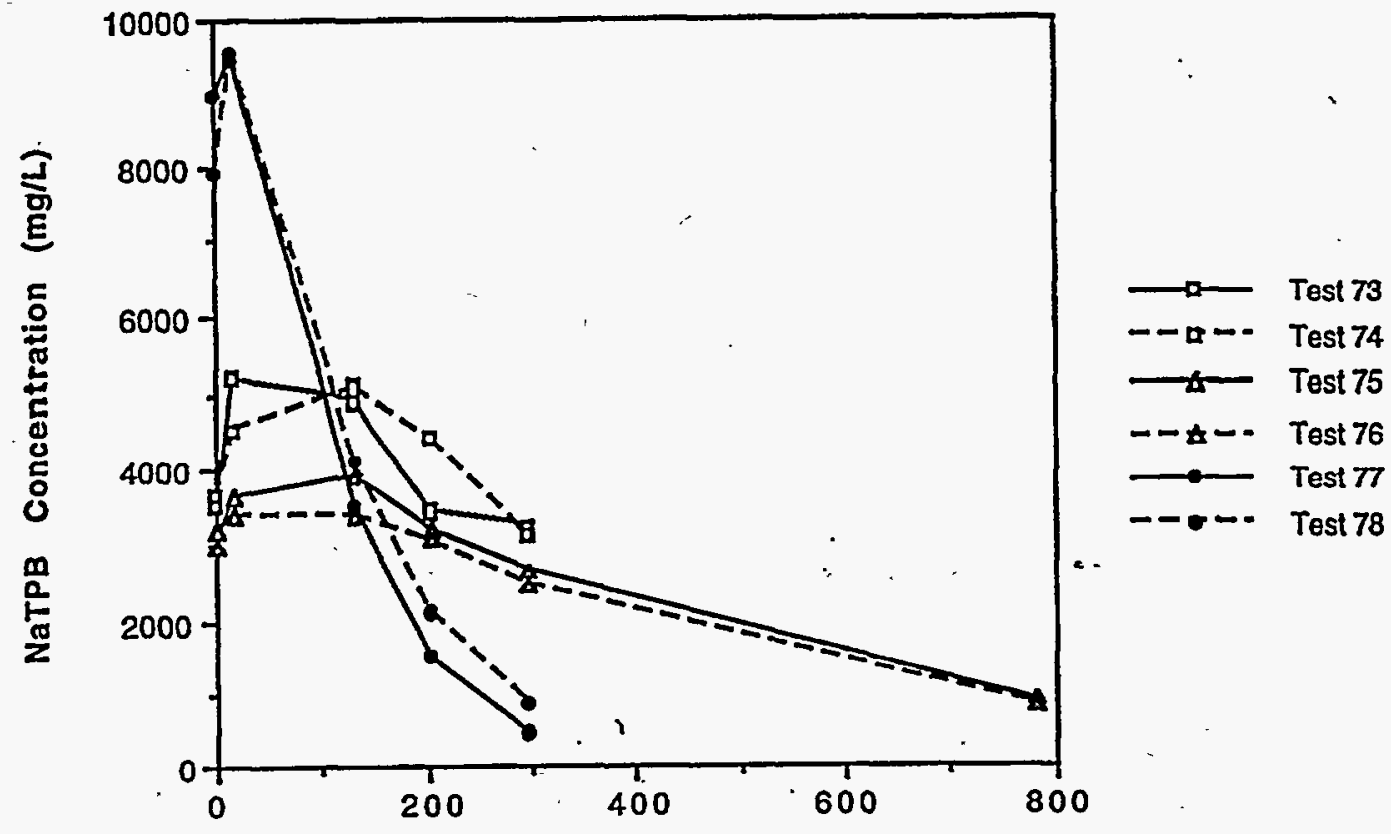

Time (h)

\subsection{Effect of Uranium}

The following summary table lists rate constants obtained from tests investigating the influence of uranium. The data shows nearly the same rate of NaTPB decomposition in the four tests. Figure 2, which provides a graphical representation of NaTPB concentration with respect to time, shows the same result. Therefore, uranium appears inert in the test system and does not catalyze NaTPB decomposition under the conditions tested.

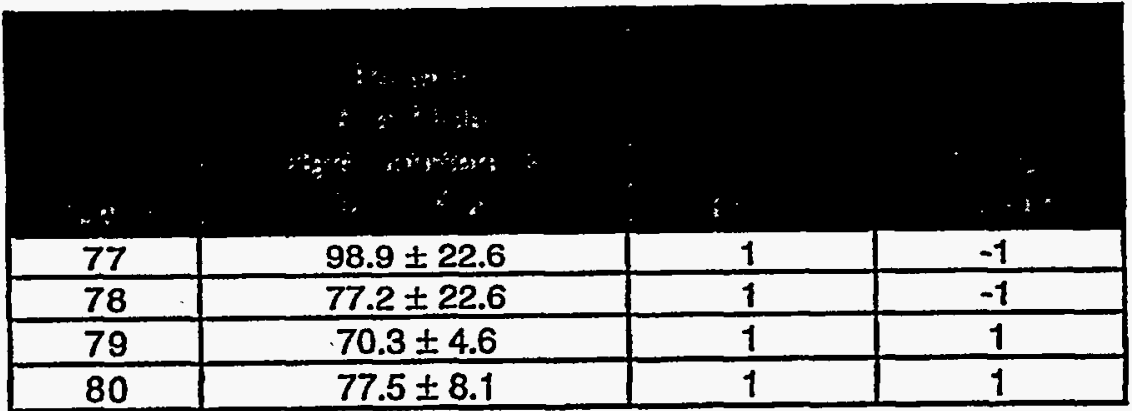

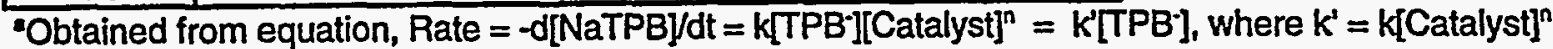

- 1 indicates the ECC system present with concentrations listed in Table 1.

$c_{-1} 1$ indicates uranium absent from the test. 1 indicates uranium added to the test. 
Figure 2. Demonstration of the effect of uranium on NaTPB reactivity.

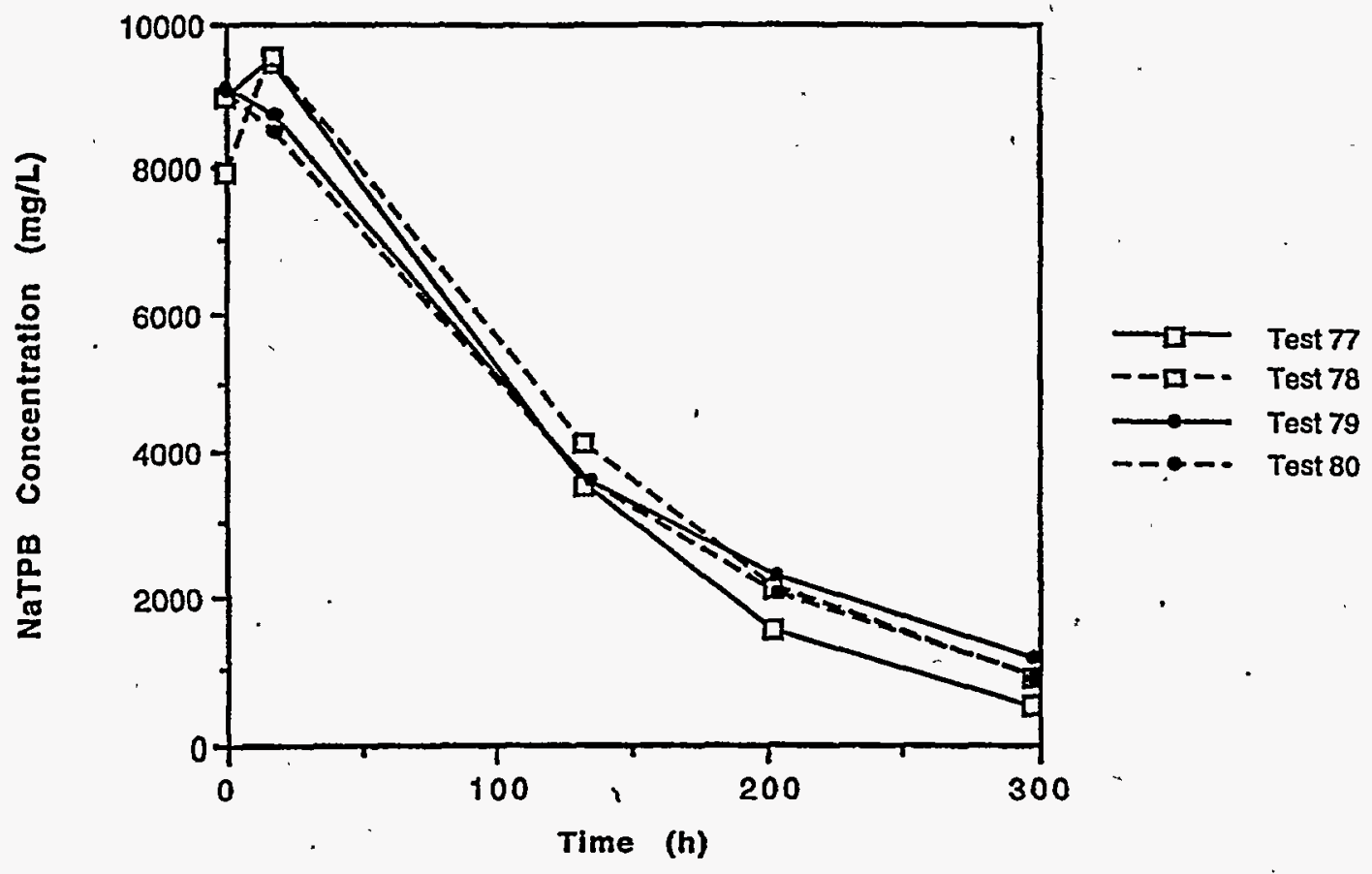

\subsection{Effect of Continuous Irradiation}

The summary table below lists rate constants obtained from continuous irradiation test program. These tests (Tests 81 through 86 ) occurred at $45^{\circ} \mathrm{C}$. However, Tests 81 and 82 incurred a temperature excursion to $65^{\circ} \mathrm{C}$ during the early stages of testing. Records indicate the oven remained at approximately $65^{\circ} \mathrm{C}$ for at least 8.5 hours but no more than 58 hours. The temperature excursion occurred between 140 and 200 hours in the reaction. Because of the temperature excursion, data from Tests 81 and 82 obtained after 138 hours of reaction does not provide reliable insight to the kinetics.

\begin{tabular}{|c|c|c|c|}
\hline \multicolumn{5}{|c|}{} & \\
\hline & & & \\
\hline 81 & $83.9 \pm 25.8^{d}$ & 1 & -1 \\
\hline 82 & $81.3 \pm 30.1^{d}$ & 1 & -1 \\
\hline 83 & $20.9 \pm 5.2$ & -1 & 1 \\
\hline 84 & $26.7 \pm 7.8$ & -1 & 1 \\
\hline 85 & $25.5 \pm 7.9$ & 1 & 1 \\
\hline 86 & $24.1 \pm 6.8$ & 1 & 1 \\
\hline
\end{tabular}

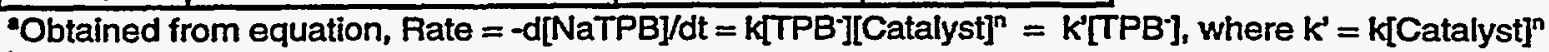

${ }^{6}-1$ indicates the ECC system absent from the test. 1 indicates the ECC system present with concentrations listed in Table 1.

$c-1$ indicates the test was not continuously irradiated. 1 indicates continuous irradiation.

Data from Tests 81 and 82 not reliable for kinetic analysis due to a temperature excursion during testing. 
Figure 3. Demonstration of the effect of 3.1 E4 rad/h continuous irradiation on tests with and without the ECC system.

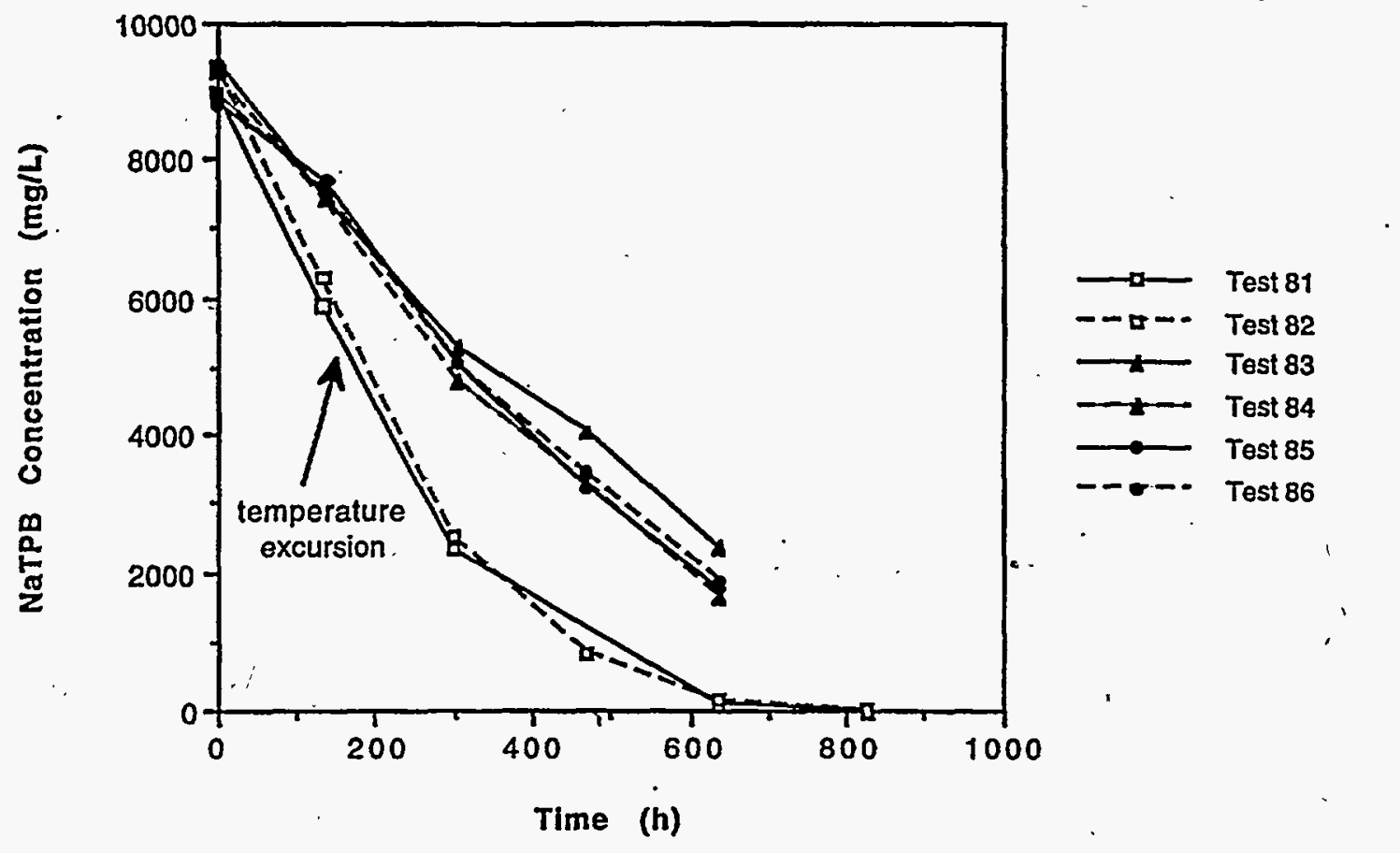

Rate constants obtained from tests 83 through 86 agree within measurement error. The data indicate continuous irradiation, in the absence of the ECC system, produces a small degree of decomposition. Furthermore, comparison of Tests 83 through 86 indicate that either a slow reaction of the ECC system at $45^{\circ} \mathrm{C}$ or that the continuous irradiation suppresses the ECC induced reaction. Data obtained from Tests 81 and 82 prior to the temperature excursion suggest the suppressed reaction is most likely since the initial rate of decomposition of Tests 81 and 82 exceeds that of Tests 85 and 86 . Inspection of Figure 3 further highlights this conclusion. Even with the temperature excursion, the data conclusively demonstrate that continuous irradiation does not promote an accelerated catalytic NaTPB decomposition.

\subsection{Conclusions}

The last set, Phase D, of statistical design catalyst identification tests finished. Testing determined uranium does not influence the ECC system and does not catalyze NaTPB decomposition under the test conditions. Additionally, pre-irradiation (i.e., a 200 Mrad dose) does not promote accelerated catalytic decomposition. Data strongly suggests that pre-irradiation reduces NaTPB decomposition, most likely through catalyst deactivation. Furthermore, continuous irradiation exhibits the same trends (i.e., it does not promote accelerated catalytic decomposition and appears to suppress reactivity).

\subsection{Path Forward}

The program, as scheduled, does not include further catalyst identification testing. The complex catalyst system containing palladium, benzene, diphenylmercury, and phenylborates provides the most rapid decomposition of NaTPB observed. The work to date does not fully explain the role of each species in the catalyst system. For example, other work shows nearly as rapid reaction in the absence of diphenylmercury. [Ref. 6] Also, the work did not attempt to identify if onlyone of the added phenylborates promotes the reaction. Similarly, the earlier work shows a complex dependency on the present of benzene. Further work could help understand these features. 
S. D. Fink

\subsection{Tables}

Table 1. Enhanoed Comprehensive Catalyst (ECC) components for Phase D statistical design catalyst identification tests with target concentrations provided in parentheses.

Inactive Components

methanol ( $5 \mathrm{mg} / \mathrm{L})$

isopropanol (50 $\mathrm{mg} / \mathrm{L})$

phenol (125 mg/L)

biphenyl (150 mg/)

copper (1.7 mg/L)

cadmium $(0.4 \mathrm{mg} / \mathrm{L})$

molybdenium (12 mgh)

cerium (0.3 mg $/$ )

silicon (16 mg/L)

selenium (1 $\mathrm{mg} / \mathrm{L})$

arsenic (0.04 $\mathrm{mg} / \mathrm{L})$

tin (2.1 mg/)

cobalt $(0.04 \mathrm{mg} / \mathrm{L})$

calcium (12.2 $\mathrm{mg} /$ )

strontium (0.1 $\mathrm{mg} / \mathrm{L})$

lanthanum $(0.05 \mathrm{mg} / \mathrm{L})$

iron (579 mg/L)

chromium (64 mg/L)

zinc (12.8 mg/L)

manganese (118 $\mathrm{mg} / \mathrm{L}$ )

nickel (50 mg/L)

aluminum (96 mg/)

magnesium (2 $\mathrm{mg} / \mathrm{L}$ )

zirconium (50 mg/ $)$

lead (6 mg/L)

monosodium titanate ( $2 \mathrm{~g} / \mathrm{L}$ )

ruthenium (5.4 mg/L)

rhodium (1.4 mg/L)

silver (6.8 $\mathrm{mg} / \mathrm{L})$

\section{Active Organics}

benzene $(720 \mathrm{mg} / \mathrm{L})$

diphenyimercury (150 mg/L)

Phenylborate intermediates

- 3PB (125 mg/L)

- 2PB (125 mg/L)

- 1PB (125 mg/h)

Active Metal

palladium (2.6 mg/L) 
S. D. Fink

Table 2: Phase D statistical designs for miscellaneous (i.e., pre-irradiation, uranium, and continuous irradiation) catalyst identification testing.

Part A: Pre-irradiation and uranium test design.

\begin{tabular}{|c|c|c|c|c|}
\hline Test \# & ECC $^{\mathrm{a}}$ & $\begin{array}{c}200 \text { Mrad } \\
\text { Pre-irradiation }^{\mathrm{b}}\end{array}$ & $\begin{array}{c}340 \mathrm{mg} / \mathrm{L} \\
\text { Uranium }^{\mathrm{c}}\end{array}$ & $\begin{array}{c}\text { Temperature } \\
\text { ('C) }\end{array}$ \\
\hline 73 & -1 & 1 & -1 & 55 \\
\hline 74 & -1 & 1 & -1 & 55 \\
\hline 75 & 1 & 1 & -1 & 55 \\
\hline 76 & 1 & 1 & -1 & 55 \\
\hline 77 & 1 & -1 & -1 & 55 \\
\hline 78 & 1 & -1 & -1 & 55 \\
\hline 79 & 1 & -1 & 1 & 55 \\
\hline 80 & 1 & -1 & 1 & 55 \\
\hline
\end{tabular}

-1 indicates the ECC system absent from the test. 1 indicates the ECC system present with concentrations listed in Table 1.

b -1 indicates the test was not pre-irradiated. 1 indicates pre-irradiation.

c -1 indicates uranium absent from the test. 1 indicates uranium added to the test.

Part B: Pre-irradiation and uraniumitest design.

\begin{tabular}{|c|c|c|c|}
\hline & & $\begin{array}{c}3.1 \text { E4 rad/h } \\
\text { Continuous } \\
\text { irradiation }\end{array}$ & $\begin{array}{c}\text { Temperature } \\
\left({ }^{\circ} \mathrm{C}\right)\end{array}$ \\
\hline Test \# & ECC $^{\mathrm{a}}$ & -1 & 45 \\
\hline 81 & 1 & -1 & 45 \\
\hline 82 & 1 & 1 & 45 \\
\hline 84 & -1 & 1 & 45 \\
\hline 85 & -1 & 1 & 45 \\
\hline 86 & 1 & 1 & 45 \\
\hline
\end{tabular}

-1 indicates the ECC system absent from the test. 1 indicates the ECC system present with concentrations listed in Table 1.

b -1 indicates the test was not continuously irradiated. 1 indicates continuously irradiation. 
Table 3. Standard tetraphenylborate slumy simulant for Phase D statistical design catalyst identification tests (target concentrations).

\begin{tabular}{|c|c|}
\hline Component & $\begin{array}{c}2.7 \mathrm{M} \mathrm{Na}^{+} \\
\text {Slurry } \\
\text { Concentration }\end{array}$ \\
\hline sodium & $2.66 \mathrm{M}$ \\
\hline hydroxide & $1.49 \mathrm{M}$ \\
\hline nitrite & $0.39 \mathrm{M}$ \\
\hline nitrate & $0.38 \mathrm{M}$ \\
\hline aluminate & $0.09 \mathrm{M}$ \\
\hline sulfate & $0.006 \mathrm{M}$ \\
\hline carbonate & $0.10 \mathrm{M}$ \\
\hline chloride & $0.008 \mathrm{M}$ \\
\hline fluoride & $0.004 \mathrm{M}$ \\
\hline phosphate & $0.003 M$ \\
\hline $\mathrm{TPB}^{-(\mathrm{b})}$ & $0.02 \mathrm{M}$ \\
\hline NaTPB (insoluble) & $0 \mathrm{~g} / \mathrm{L}$ \\
\hline KTPB (ins & $48 \mathrm{~g} / \mathrm{L}$ \\
\hline
\end{tabular}

Theoretical (estimated from filtrate density). [Ref. 12]

'Theoretical (calculated using sodium ion concentration). [Ref. 13]

Initial concentration represents $\sim 4$ wt \% KTPB. 
Table 4. Soluble sodium tetraphenylborate, triphenylborane (3PB) and diphenylborinic acid (2PB) concentrations versus time for Test 73 .

\begin{tabular}{|c|c|c|c|}
\hline $\begin{array}{c}\text { Reaction } \\
\text { Time (h) }\end{array}$ & $\begin{array}{c}\text { Soluble NaTPB } \\
\text { (mg/h) }\end{array}$ & $\begin{array}{c}\text { 3PB } \\
\text { (mg/L) }\end{array}$ & $\begin{array}{c}2 \mathrm{~PB} \\
(\mathrm{mg} / \mathrm{L})\end{array}$ \\
\hline 0.0 & 3544 & $<10$ & $<10$ \\
\hline 17.3 & 5194 & 9 & $<10$ \\
\hline 132.5 & 4892 & $<10$ & $<10$ \\
\hline 202.9 & 3449 & 20 & $<10$ \\
\hline 297.1 & 3273 & 20 & $<10$ \\
\hline
\end{tabular}

Table 5. Soluble sodium tetraphenylborate, triphenylborane (3PB) and diphenylborinic acid (2PB) concentrations versus time for Test 74 .

\begin{tabular}{|c|c|c|c|}
\hline $\begin{array}{c}\text { Reaction } \\
\text { Time }(\mathrm{h})\end{array}$ & $\begin{array}{c}\text { Soluble NaTPB } \\
(\mathrm{mg} / \mathrm{L})\end{array}$ & $\begin{array}{c}\text { 3PB } \\
(\mathrm{mg} / \mathrm{L})\end{array}$ & $\begin{array}{c}2 \mathrm{~PB} \\
(\mathrm{mg} / \mathrm{L})\end{array}$ \\
\hline 0.0 & 3652 & $<10$ & $<10$ \\
\hline 17.3 & 4592 & 3 & $<10$ \\
\hline 132.5 & 5073 & $<10$ & $<10$ \\
\hline 202.9 & 4475 & 13 & $<10$ \\
\hline 297.1 & 3126 & 9 & $<10$ \\
\hline
\end{tabular}

Table 6. Soluble sodium tetraphenylborate, triphenylborane-(3PB) and diphenylborinic acid (2PB) concentrations versus time for Test 75 .

\begin{tabular}{|c|c|c|c|}
\hline $\begin{array}{c}\text { Reaction } \\
\text { Time (h) }\end{array}$ & $\begin{array}{c}\text { Soluble NaTPB } \\
(\mathrm{mg} / \mathrm{L})\end{array}$ & $\begin{array}{c}3 \mathrm{~PB} \\
(\mathrm{mg} / \mathrm{L})\end{array}$ & $\begin{array}{c}2 \mathrm{~PB} \\
(\mathrm{mg} / \mathrm{L})\end{array}$ \\
\hline 0.0 & 2995 & 101 & 25 \\
\hline 17.3 & 3660 & 235 & 43 \\
\hline 132.5 & 3918 & 835 & 39 \\
\hline 202.9 & 3209 & 1011 & $<10$ \\
\hline 297.1 & 2698 & 1130 & 47 \\
\hline 781.3 & 935 & 2006 & 77 \\
\hline
\end{tabular}

Table 7. Soluble sodium tetraphenylborate, triphenylborane (3PB) and diphenylborinic acid (2PB) concentrations versus time for Test 76.

\begin{tabular}{|c|c|c|c|}
\hline $\begin{array}{c}\text { Reaction } \\
\text { Time }(\mathrm{h})\end{array}$ & $\begin{array}{c}\text { Soluble NaTPB } \\
(\mathrm{mg} / \mathrm{h})\end{array}$ & $\begin{array}{c}\text { 3PB } \\
\text { (mg/L) }\end{array}$ & $\begin{array}{c}\text { 2PB } \\
(\mathrm{mg} / \mathrm{L})\end{array}$ \\
\hline 0.0 & 3206 & 98 & 42 \\
\hline 17.3 & 3419 & 233 & 46 \\
\hline 132.5 & 3408 & 684 & 42 \\
\hline 202.9 & 3081 & 946 & $<10$ \\
\hline 297.1 & 2500 & 1084 & 81 \\
\hline 781.3 & 855 & 1835 & 57 \\
\hline
\end{tabular}


Table 8. Soluble sodium tetraphenylborate, triphenylborane (3PB) and diphenylborinic acid (2PB) concentrations versus time for Test 77 .

\begin{tabular}{|c|c|c|c|}
\hline $\begin{array}{c}\text { Reaction } \\
\text { Time }(\mathrm{h})\end{array}$ & $\begin{array}{c}\text { Soluble NaTPB } \\
(\mathrm{mg} / \mathrm{L})\end{array}$ & $\begin{array}{c}\text { 3PB } \\
(\mathrm{mg} / \mathrm{L})\end{array}$ & $\begin{array}{c}\text { 2PB } \\
(\mathrm{mg} / \mathrm{L})\end{array}$ \\
\hline 0.0 & 8948 & 77 & 114 \\
\hline 17.3 & 9424 & 533 & 136 \\
\hline 132.5 & 3531 & 2850 & 1305 \\
\hline 202.9 & 1508 & 2997 & 2036 \\
\hline 297.1 & 495 & 2388 & 2516 \\
\hline
\end{tabular}

Table 9. Soluble sodium tetraphenylborate, triphenylborane (3PB) and diphenylborinic acid (2PB) concentrations versus time for Test 78 .

\begin{tabular}{|c|c|c|c|}
\hline $\begin{array}{c}\text { Reaction } \\
\text { Time }(\mathrm{h})\end{array}$ & $\begin{array}{c}\text { Soluble NaTPB } \\
\text { (mg/) }\end{array}$ & $\begin{array}{c}\text { 3PB } \\
\text { (mg/L) }\end{array}$ & $\begin{array}{c}\text { 2PB } \\
\text { (mg/L) }\end{array}$ \\
\hline 0.0 & 7906 & 66 & 81 \\
\hline 17.3 & 9512 & 308 & 105 \\
\hline 132.5 & 4126 & 3099 & 1001 \\
\hline 202.9 & 2123 & 3610 & 1561 \\
\hline 297.1 & 882 & 3373 & 2098 \\
\hline
\end{tabular}

Table 10. Soluble sodium tetraphenylborate, triphenylborane (3PB) and diphenylborinic acid (2PB) concentrations versus time for Test 79 .

\begin{tabular}{|c|c|c|c|}
\hline $\begin{array}{c}\text { Reaction } \\
\text { Time }(\mathrm{h})\end{array}$ & $\begin{array}{c}\text { Soluble NaTPB } \\
(\mathrm{mg} / \mathrm{L})\end{array}$ & $\begin{array}{c}3 \mathrm{~PB} \\
(\mathrm{mg} / \mathrm{L})\end{array}$ & $\begin{array}{c}2 \mathrm{2PB} \\
(\mathrm{mg} / \mathrm{L})\end{array}$ \\
\hline 0.0 & 9082 & 80 & 141 \\
\hline 18.1 & 8704 & 333 & 121 \\
\hline 134.4 & 3625 & 3285 & 719 \\
\hline 203.7 & 2294 & 3844 & 1002 \\
\hline 298.4 & 1152 & 3806 & 1563 \\
\hline
\end{tabular}

Table 11. Soluble sodium tetraphenylborate, triphenylborane (3PB) and diphenylborinic acid (2PB) concentrations versus time for Test $\mathbf{8 0}$.

\begin{tabular}{|c|c|c|c|}
\hline $\begin{array}{c}\text { Reaction } \\
\text { Time }(\mathrm{h})\end{array}$ & $\begin{array}{c}\text { Soluble NaTPB } \\
\text { (mg/L) }\end{array}$ & $\begin{array}{c}\text { 3PB } \\
\text { (mg/L) }\end{array}$ & $\begin{array}{c}2 \mathrm{mB} \\
\text { (mg/L) }\end{array}$ \\
\hline 0.0 & 9028 & 80 & 135 \\
\hline 18.1 & 8465 & 271 & 123 \\
\hline 134.4 & 3601 & 3304 & 775 \\
\hline 203.7 & 2055 & 3699 & 1080 \\
\hline 298.4 & 899 & 3601 & 2311 \\
\hline
\end{tabular}


Table 12. Soluble sodium tetraphenylborate, triphenylborane (3PB) and diphenylborinic acid (2PB) concentrations versus time for Test 81 .

\begin{tabular}{|c|c|c|c|}
\hline $\begin{array}{c}\text { Reaction } \\
\text { Time }(\mathrm{h})\end{array}$ & $\begin{array}{c}\text { Soluble NaTPB } \\
\text { (mg/L) }\end{array}$ & $\begin{array}{c}\text { 3PB } \\
\text { (mg/L) }\end{array}$ & $\begin{array}{c}\text { 2PB } \\
\text { (mg/L) }\end{array}$ \\
\hline 0.0 & 8975 & 73 & 130 \\
\hline 134.0 & 5848 & 2780 & 480 \\
\hline 300.7 & 2318 & 3696 & 1422 \\
\hline 637.5 & 94 & 2857 & 2270 \\
\hline 826.1 & $<10$ & 1830 & 2319 \\
\hline
\end{tabular}

Table 13. Sóluble sodium tetraphenylborate, triphenylborane (3PB) and diphenylborinic acid (2PB) concentrations versus time for Test 82 .

\begin{tabular}{|c|c|c|c|}
\hline $\begin{array}{c}\text { Reaction } \\
\text { Time (h) }\end{array}$ & $\begin{array}{c}\text { Soluble NaTPB } \\
\text { (mg/L) }\end{array}$ & $\begin{array}{c}\text { 3PB } \\
\text { (mg/L) }\end{array}$ & $\begin{array}{c}\text { 2PB } \\
\text { (mg/L) }\end{array}$ \\
\hline 0.0 & 9308 & 74 & 133 \\
\hline 134.0 & 6273 & 2520 & 397 \\
\hline 300.7 & 2525 & 3047 & 1270 \\
\hline 468.0 & 861 & 2954 & 1424 \\
\hline 637.5 & 166 & 2444 & 1417 \\
\hline 826.1 & 9 & 1648 & 1439 \\
\hline
\end{tabular}

Table 14. Soluble sodium tetraphenylborate, triphenylborane (3PB) and diphenylborinic acid (2PB) concentrations versus time for Test 83.

\begin{tabular}{|c|c|c|c|c|}
\hline $\begin{array}{c}\text { Reaction } \\
\text { Time (h) }\end{array}$ & $\begin{array}{c}\text { Soluble NaTPB } \\
(\mathrm{mg} / \mathrm{L})\end{array}$ & $\begin{array}{c}\text { 3PB } \\
(\mathrm{mg} / \mathrm{L})\end{array}$ & $\begin{array}{c}\text { 2PB } \\
(\mathrm{mg} / \mathrm{L})\end{array}$ & $\begin{array}{c}\text { Radiation Dose } \\
\text { (Mrad) }\end{array}$ \\
\hline 0.0 & 9389 & $<10$ & $<10$ & 0.0 \\
\hline 136.6 & 7440 & 79 & 997 & 4.2 \\
\hline 302.8 & 5254 & 152 & 1503 & 9.4 \\
\hline 469.8 & 4066 & 196 & 1891 & 14.6 \\
\hline 638.0 & 2365 & 270 & 1917 & 19.8 \\
\hline
\end{tabular}

Table 15. Soluble sodium tetraphenylborate, triphenylborane (3PB) and diphenylborinic acid (2PB) . concentrations versus time for Test 84.

\begin{tabular}{|c|c|c|c|c|}
\hline $\begin{array}{c}\text { Reaction } \\
\text { Time (h) }\end{array}$ & $\begin{array}{c}\text { Soluble NaTPB } \\
(\mathrm{mg} / \mathrm{L})\end{array}$ & $\begin{array}{c}3 \mathrm{~PB} \\
(\mathrm{mg} / \mathrm{L})\end{array}$ & $\begin{array}{c}2 \mathrm{~PB} \\
(\mathrm{mg} / \mathrm{L})\end{array}$ & $\begin{array}{c}\text { Radiation Dose } \\
(\text { Mrad })\end{array}$ \\
\hline 0.0 & 9253 & $<10$ & $<10$ & 0.0 \\
\hline 136.6 & 7385 & 88 & 1048 & 4.2 \\
\hline 302.8 & 4792 & 60 & 1565 & 9.4 \\
\hline 469.8 & 3310 & 208 & 2087 & 14.6 \\
\hline 638.0 & 1631 & 261 & 2048 & 19.8 \\
\hline
\end{tabular}


Table 16. Soluble sodium tetraphenylborate, triphenylborane (3PB) and diphenylborinic acid (2PB) concentrations versus time for Test 85.

\begin{tabular}{|c|c|c|c|c|}
\hline $\begin{array}{c}\text { Reaction } \\
\text { Time }(\mathrm{h})\end{array}$ & $\begin{array}{c}\text { Soluble NaTPB } \\
(\mathrm{mg} / \mathrm{L})\end{array}$ & $\begin{array}{c}\text { 3PB } \\
(\mathrm{mg} / \mathrm{L})\end{array}$ & $\begin{array}{c}\text { 2PB } \\
(\mathrm{mg} / \mathrm{L})\end{array}$ & $\begin{array}{c}\text { Radiation Dose } \\
(\text { Mrad })\end{array}$ \\
\hline 0.0 & 8802 & 70 & 132 & 0.0 \\
\hline 136.6 & 7652 & 323 & 572 & 4.2 \\
\hline 302.8 & 5025 & 680 & 488 & 9.4 \\
\hline 469.8 & 3248 & 825 & 464 & 14.6 \\
\hline 638.0 & 1759 & 918 & 439 & 19.8 \\
\hline
\end{tabular}

Table 17. Soluble sodium tetraphenylborate, triphenylborane (3PB) and diphenylborinic acid (2PB) concentrations versus time for Test 86.

\begin{tabular}{|c|c|c|c|c|}
\hline $\begin{array}{c}\text { Reaction } \\
\text { Time }(\mathrm{h})\end{array}$ & $\begin{array}{c}\text { Soluble NaTPB } \\
(\mathrm{mg} / \mathrm{L})\end{array}$ & $\begin{array}{c}3 \mathrm{~PB} \\
(\mathrm{mg} / \mathrm{L})\end{array}$ & $\begin{array}{c}2 \mathrm{~PB} \\
(\mathrm{mg} / \mathrm{L})\end{array}$ & $\begin{array}{c}\text { Radiation Dose } \\
(\mathrm{Mrad})\end{array}$ \\
\hline 0.0 & 8896 & 71 & 133 & 0.0 \\
\hline 136.6 & 7526 & 309 & 584 & 4.2 \\
\hline 302.8 & 5007 & 485 & 517 & 9.4 \\
\hline 469.8 & 3458 & 728 & 472 & 14.6 \\
\hline 638.0 & 1901 & 831 & 466 & 19.8 \\
\hline
\end{tabular}

Table 18. Kinetics data for Phase $D$ statistical design catalyst identification Tests 73 through 86 .

\begin{tabular}{|c|c|c|}
\hline Test & $\begin{array}{l}\text { Pseudo first } \\
\text { Order Rate } \\
\text { Constant } t^{\mathrm{a}}, \mathrm{k}^{\mathrm{s}} \\
\left(\mathrm{h}^{-1} \cdot 1 \mathrm{E}-4\right)\end{array}$ & Comments ${ }^{b}$ \\
\hline 73 & $9.2 \pm 26.7^{c}$ & no reaction detected \\
\hline 74 & $5.8 \pm 26.6^{c}$ & no reaction detected \\
\hline 75 & $17.1 \pm 9.0^{c}$ & \\
\hline 76 & $18.0 \pm 6.7^{c}$ & \\
\hline 77 & $98.9 \pm 22.6^{6}$ & \\
\hline 78 & $77.2 \pm 22.6^{6}$ & \\
\hline 79 & $70.3 \pm 4.6^{c}$ & \\
\hline 80 & $77.5 \pm 8.1^{\circ}$ & \\
\hline 81 & $83.9 \pm 25.8^{d}$ & $\begin{array}{l}\text { Oven temperature excursion - data not } \\
\text { reliable for kinetic analysis }\end{array}$ \\
\hline 82 & $81.3 \pm 30.1^{d}$ & $\begin{array}{l}\text { Oven temperature excursion - data not } \\
\text { reliable for kinetic analysis }\end{array}$ \\
\hline 83 & $20.9 \pm 5.2^{d}$ & \\
\hline 84 & $26.7 \pm 7.8^{d}$ & \\
\hline 85 & $25.5 \pm 7.9^{d}$ & \\
\hline 86 & $24.1 \pm 6.8^{d}$ & \\
\hline
\end{tabular}

'Obtained from equation, Rate $=-\mathrm{d}[\mathrm{NaTPB}] / \mathrm{dt}=\mathrm{k}[\mathrm{TPB}]\left[\right.$ Catalyst $^{\mathrm{n}}=\mathrm{k}^{\prime}\left[\mathrm{TPB}^{\prime}\right]$, where $\mathrm{k}^{\prime}=\mathrm{k}\left[\right.$ Catalyst ${ }^{\mathrm{n}}$

b "No reaction detected" indicates [TPB] data not statistically significant at a 95\% confidence level. 3PB and $2 \mathrm{~PB}$ data verifies the lack of a significant reaction.

'Tests conducted at $55^{\circ} \mathrm{C}$.

Tests conducted at $45^{\circ} \mathrm{C}$. 


\subsection{Internal References}

1. D. D. Walker, M. J. Barnes, C. L. Crawford, R. F. Swingle, R. A. Peterson, M. S. Hay, and S. D. Fink, "Decomposition of Tetraphenylborate in Tank 48H (U)", WSRC-TR-96-0113, Rev, 0, May 10, 1996.

2. M. J. Barnes, C. L. Crawford, C. A. Nash, and T. B. Edwards, "Task Technical Plan for Sodium Tetraphenylborate Decomposition Catalyst Identification Studies (U)", WSRC-RP-96-600, Rev. 2 , June 20, 1997.

3. M. J. Barnes, C. L. Crawford, and C. A. Nash, "Sodium Tetraphenylborate Catalyst ldentification: Preliminary Studies Set 1 (U)", WSRC-TR-97-0060, March 6, 1997.

4. M. J. Barnes, "Sodium Tetraphenylborate Catalyst Identification: Preliminary Studies Set 2 (U)", WSRC-TR-97-0144, Rev. 0, March 6, 1997.

5.' M. J. Barnes, "Sodium Tetraphenylborate Catalyst Identification: Phase A Statistical Design Studies (U)", WSRC-TR-97-0210, Rev. 0, July 22, 1997.

6. M. J. Barnes, "Sodium Tetraphenylborate Catalyst Identification: Phase B and C Statistical Design Studies (U)", WSRC-TR-97-0230, Rev. 0, August 13, 1997.

7. "Department of Energy Implementation Plan for Defense Nuclear Facilities Safety Board Recommendation 96-1 to the Secretary of Energy", In-Tank Precipitation Facility at the Savannah River Site, Oćtober 1996. 1

8. A. W. Wiggins, "Soluble TPB Decomposition and Catalysis" (U), HLW-TTR-97008, November 15, 1996.

9. D. D. Walker, "Calibration of Laboratory Glassware" (U), Manual L12.1, Procedure IWT-OP-009, Rev. 3, May 8, 1995:

10. J. R. Fowler, "Sludge Composition for Each Tank and DWPF Feed Batches" (U), DPST-84-556, June 11, 1984.

11. M. J. Barnes and T. B. Edwards, "Copper Catalyzed Sodium Tetraphenylborate, Decomposition Studies (U)", WSRC-TR-96-0351, November 7, 1996.

12. D. D. Walker, data contained in Laboratory Notebook WSRC-NB-95-23, p. 88.

13. M. J. Barnes, R. A. Peterson, R. F. Swingle and C. T. Reeves, "Sodium Tetraphenylborate Solubility and Dissolution Rates (U)", WSRC-TR-95-0092, March 7, 1995. 


\section{DISTRIBUTION}

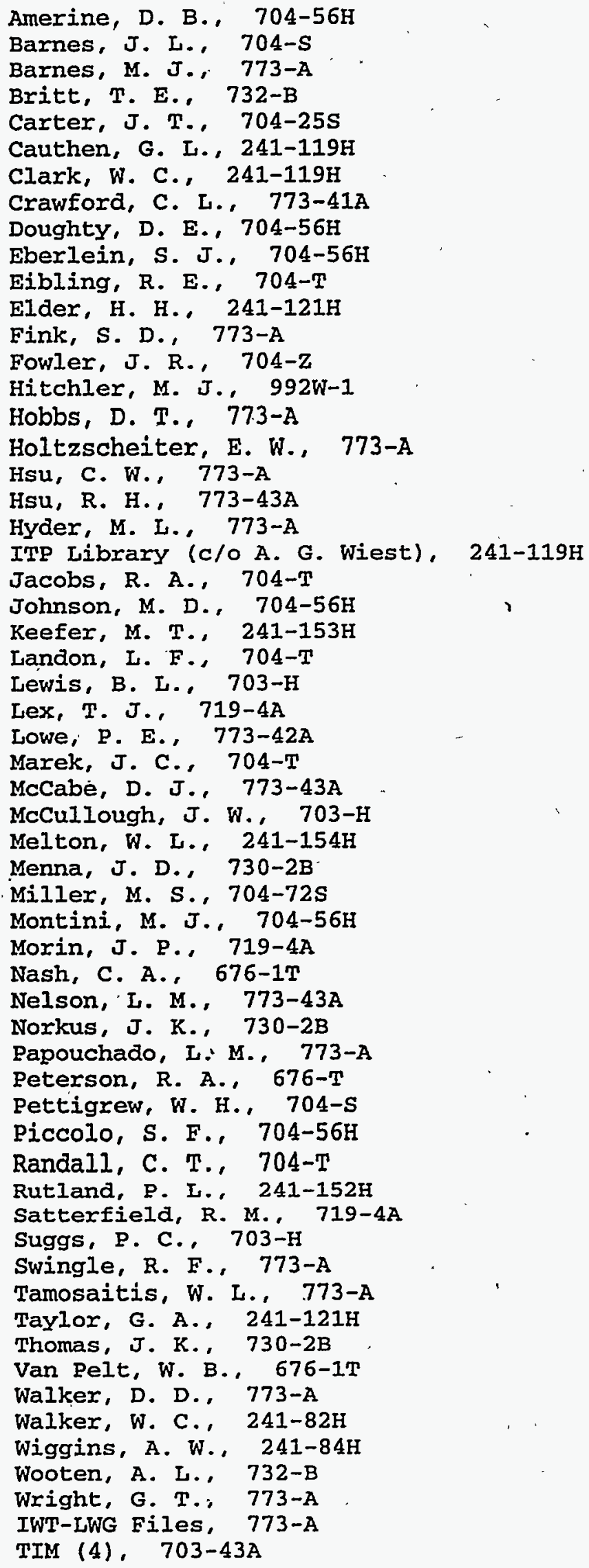

